\title{
World Demand as a Determinant of Immiserizing Growth
}

\section{Tamara Todorova}

American University in Bulgaria, Department of Economics, Blagoevgrad, Bulgaria

Email: ttodorova@aubg.bg

Received March $18^{\text {th }}, 2010$; revised May $11^{\text {th }}, 2010$; accepted July $20^{\text {th }}, 2010$.

\begin{abstract}
Theoretically economic growth could have negative effects over the growing economy when production expands for products the world demand for which is inelastic. If growth occurs in sectors and for products the world demand for which is elastic it could be expected that total revenues to domestic producers and exporters increase. Our goal is to prove that growth would be immiserizing only for products for which world demand is inelastic and expansion leads to a sizable worsening of the terms of trade. We show that there are few such commodities, namely food products and natural resources such as oil. Studying econometrically the demand function for Brazilian coffee as an example, we compare our estimation of the elasticity of demand for Brazil's exports of green coffee with other research on the world elasticity of demand for green coffee. We conclude that for manufactured products the demand for which is highly elastic it is unlikely that exporting countries fall into immiserization, therefore, growth and further participation in global trade turn out to be quite beneficial. Our conclusion is that too much emphasis is put in economic theory and trade policy on the concept of immiserizing growth which is more of a theoretical possibility than a real-life problem.
\end{abstract}

Keywords: International Trade, Immiserizing Growth, Terms of Trade, Elasticity of Demand

\section{Introduction}

Usually a country's economic performance is measured by the per capita economic growth rate where economic growth is an increase in the total output of the economy. Economic development, on the other hand, is given by the increase in the total welfare of an economy. Immiserizing growth is a situation in international trade where economic development and growth do not move in the same direction, that is, welfare decreases while economic growth is positive. The idea of immiserizing growth is expressed by Bhagwati [1] in a traditional two country, two - commodity "real" model with full employment. He proves that immiserizing growth could occur due to the deterioration of the terms of trade even if the growing economy faces an elastic foreign-offer curve [2]. Johnson [3] independently works out the conditions of this result.

In his paper "Immiserizing Growth: A Geometrical Note" Bhagwati [1] criticizes that the negative aspects of economic growth are insufficiently stressed and concludes: "economic expansion increases output which,

${ }^{1}$ Italics in the original. however, might lead to a sufficient deterioration in the terms of trade to offset the beneficial effect of expansion and reduce the real income of the growing economy" [1]. ${ }^{1}$ Dinopoulos [4] considers Bhagwati's paper one of the most influential in the theory of commercial policy demonstrating formally the possibility of immiserizing growth. For Dinopoulos Bhagwati's fundamental insight is "an elegant application of the theory of the second best." Other economists [5] do not regard the concept of immiserizing growth as a real-world issue.

Johnson [6] shows the possibility for real income to fall when growth occurs in protected import-substituting industries even in the case of small open economies. His model indicates that the fall in a country's terms of trade is not a necessary condition for immiserizing growth. Other studies prove that building tariff barriers with the aim to attract foreign investment can also bring the economy into immiserization [7-9]. Hamada and Iwata [10] show that large increases in the price of imported oil can also lead to immiserizing growth. Sawada [11] recognizes that immiserizing growth must involve some form of suboptimality and arises in the presence of a sufficiently large distortion in the economy. Thus, immis- 
erizing growth could be avoided by removing the distortion. Sawada [11] investigates the empirical reality of immiserizing growth using revealed preference theory to measure welfare and evaluate welfare movements of individual countries over time.

In order to understand the effects of the shifts in world supply resulting from economic growth we should study those shifts in relation to world demand. Just like world supply changes as a result of the changing production abilities of countries, so does world demand shift as a result of foreign aid, war reparations, and other international transfers of income. In the case of import tariffs and export subsidies shifts in world supply and demand occur simultaneously and affect in various ways the international terms of trade. To study economic growth from the perspective of supply only is one-sided. The effects of an expanding economy should be analysed with respect to the condition of world demand. Once that condition is taken into account, immiserizing growth may not seem so likely for developing countries.

Growth at home should be good when a country can expand its production capacity and, hence, sell more of its product to the world market. Bhagwati [1] argues that the benefits of growth may be lost to foreign consumers who would enjoy lower prices once the country's exports expand. The goal of this paper is to show that not always would lower prices on the world market, resulting from economic growth, hurt domestic producers. This would be the result with highly inelastic world demand. If we assume trade in a product the demand for which is generally inelastic, only then would domestic growth have negative effect on the economy. In cases of elastic demand for the exported product economic growth may actually benefit an economy irrespective of the fact that world terms of trade are worsening for the expanding economy.

The paradox presented by Bhagwati [1] is that an open economy experiencing an expansion in its productive capacity as a result of economic growth or technological progress can become worse off if its terms of trade deteriorate sufficiently and offset the beneficial effects of economic growth. The word "sufficiently" here is key to understanding how and if immiserizing growth might occur. We argue that immiserizing growth is less likely to occur than is commonly believed. As the possibility of immiserizing growth is smaller, the analysis of immiserizing growth, which served as the basis for the development of the theory of distortions and welfare and "which constitutes the backbone of the modern theory of commercial policy" [4] should perhaps be given less weight in trade theory. The role of immiserizing growth has been exaggerated, while it has impacted a number of fields such as trade policy, welfare economics, development economics and lately the new growth theory.

Bhagwati [1] discusses the conditions under which such immiserizing growth should occur. He assumes a two-country model where one country experiences growth whereas the rest of the world (the other country) does not. He concludes that the effect of economic growth will be positive if "the terms of trade will not move against the growing country enough to deprive it of all gain from growth." The effect will be negative if "the price of imports will have to rise still further to preserve equilibrium, and the growing country will actually be made worse off by growth."

According to Bhagwati [1] the possibility of immiserizing growth is increased if the ratio of domestic production to imported goods is small, if the constant-utility demand-elasticity for imported goods with respect to a change in the price of imported goods, is small, and if the elasticity in supply of imported goods when production shifts along the production-possibility curve in response to a change in the price of imported goods, is small. He discusses $\eta_{x}$, the elasticity of the rest-of-the-world's demand for imports in response to an infinitesimal change in the terms of trade and the elasticity, and $r_{m}$, the elasticity of the rest-of-the-world's supply of its exports to the growing country in response to an infinitesimal shift in the terms of trade where $\eta_{x}-r_{m}=1$. He does not discuss elasticity in the context of the relative demand for the exported commodity in terms of the imported one.

Krugman and Obstfeld [5] underline the limitations of Bhagwati's analysis. According to them strongly exportbiased growth must be combined with very steep relative supply $R S$ and relative demand $R D$ curves, so that the change in the terms of trade is large enough to offset the initial favorable effects of an increase in a country's productive capacity. We argue that what is important is the steepness of the world relative demand for the good. Inelastic relative demand for the respective commodity the production of which is expanding will lead the country into immiserization. If however world relative demand $R D$ is elastic, immiserizing growth would hardly occur or its consequences for the economy will be minor.

Commodities for which countries may face immiserizing growth are agricultural goods such as coffee, cocoa, cotton, sugar, tea, tobacco, etc. These are commodities the demand for which is relatively price - inelastic where production expansion may result in lower prices, lower revenues and lower profitability [12]. This problem known as the "adding-up" problem is the same as the one introduced in the literature by Bhagwati [1] and Johnson [13]. Because demand for such goods is price- 
inelastic increased production and exports can lower world prices and reduce net export revenue. Akiyama and Larson [12] discuss the adding-up problem in relation to policy and development strategies for major agricultural export commodities in Sub-Saharan Africa. They find that cocoa faces the most serious adding-up problem as its elasticity of export revenue with respect to volume, $E R V$, is negative implying that Sub-Saharan Africa's export revenues will fall with an increase in exports. They also find that the adding-up problem is less serious for coffee, tea and burley tobacco. In the cases of cocoa in Cote D'Ivoire and Ghana, tea in Kenya and burley tobacco in Malawi, new investments are likely to affect international prices.

Imran and Duncan [14] discuss that when demand for a country's exports is inelastic restrictions on its exports will increase its national welfare and therefore an optimal export tax should be sought. They examine the effect of export taxes in major exporting countries on producer prices, production, export prices and export revenues. Imran and Duncan [14] estimate the short-run import demand elasticity for cocoa to be -0.2 and the long-run one to be -0.4 . Similarly, for tea they find that the short-run elasticity is around -0.2 while the long-run elasticity is about -0.4 . Demand for coffee is even less elastic with values of -0.19 and -0.23 in the short and in the long run, respectively. They find relatively higher short- and long-run price elasticities for natural rubber. Table 1 gives the results of these estimates.

The import demand elasticity facing each supplier is inversely related to its share in the world market and inversely related to its optimal export tax. Thus, for cocoa Cote D'Ivoire faces the least elastic demand because it holds the largest share among several major producers including Ghana, Brazil, Cameroon and Nigeria holding a total of $80 \%$ of world exports of cocoa.

Hallam et al. [15] find that traditional agricultural commodities are likely to encounter adding-up problems. They give the example of wheat the own-price elasticity for which lies between -0.2 and -0.6 according to the World Food Model of FAO. The price elasticity of demand for maize lies between -0.2 and -0.55 . Traditional commodities that are produced by developing countries are also subject to low-elasticity of demand. The estimate

Table 1. Import demand elasticities for selected commodities as estimated by Imran and Duncan [14].

\begin{tabular}{ccc}
\hline \multirow{2}{*}{ Commodity } & Short-Run Import & Long-Run Import Demand \\
& Demand Elasticity & Elasticity \\
\hline Cocoa & $-0.17 \sim-0.25$ & $-0.34 \sim-0.43$ \\
Tea & $-0.17 \sim-0.3$ & -0.38 \\
Coffee & $-0.15 \sim-0.19$ & -0.23 \\
Natural rubber & -0.27 & -0.76 \\
\hline
\end{tabular}

of the own - price elasticity of demand for coffee using the World Coffee Model of FAO lies between -0.1 and -0.37 . Hallam et al. [15] conclude that the high concentration of market shares in traditional agricultural exports exacerbates the adding-up problem. At the same time, in their study of non-traditional agricultural goods such as asparagus, avocado, pineapples, etc., they find that world demand for those is relatively price-elastic (as shown in Table 2), which leaves little potential for immiserizing growth.

Hallam et al. [15] estimate that the world price elasticity of demand is less than 1 for commodities such as green beans, green corn and mangoes (see Table 2). At the same time, these scholars do not identify serious adding-up problems for the world market of asparagus (except for China due to its large share of world production), avocados (except Mexico and Colombia), green peas (except India and China), and pineapples (except Asia). They find that a potential adding-up problem exists for cabbage and green beans in Asia and particularly in China. At the same time, African and South American producers of these two commodities face high elasticities of demand and do not appear to be subject to adding-up problems. Such problems exist for all producers on the world market for green corn.

Section 1 of the paper is an introduction and literature review. Section 2 elaborates on the theoretical grounds of growth, growth bias and immiserizing growth. It also gives the determinants of world relative demand in relation to the possibility of immiserizing growth and builds up our theoretical model. Section 3 discusses the data and the evaluation procedure giving the results of our econometric study. The paper ends with conclusions.

\section{The Theoretical Model}

Is growth good or bad? Economic growth in other countries may be good for our economy because it means larger markets to export to. It may also mean changing terms of trade where the relative price of a given commodity may increase or decrease. Growth abroad may as

Table 2. Own-price demand elasticities for selected nontraditional agricultural commodities as estimated by Hallam et al. [15].

\begin{tabular}{cc}
\hline Non-Traditional Agricultural & Own-Price Demand Elasticity \\
Commodity & -1.69 \\
\hline Asparagus & -2.67 \\
Avocados & -1.11 \\
Cabbages & -1.14 \\
Green Peas & -0.7 \\
Green Beans & -0.9 \\
Green Corn & -1.35 \\
Pineapples & -0.84 \\
Mangoes & \\
\hline
\end{tabular}


well be bad for us because it may foster foreign competition for our goods.

Generally, domestic growth is good because it allows expanding the consumption abilities of a country. By moving to a higher production possibility frontier ( $P P F)$ curve the country can afford to move to a higher community indifference curve, which increases its potential for consumption. A country producing two goods, as shown in Figure 1, can expand its consumption (as shown with a shift to a higher community indifference curve from $C$ to $C^{\prime}$ ) while it exports more cloth due to economic growth. We assume that the quantity of food produced is $Q_{F}$ and that of cloth is $Q_{C}$. The prices of the two goods are, respectively, $P_{F}$ and $P_{C}$.

The causes of growth are generally presumed to be sudden increases in a country's resources or improvements in the efficiency of using these resources. Technological progress and innovation can drive a country's economic prosperity although the country itself may not experience an inflow of new resources.

Most often growth is biased to a particular sector or product as the expansion usually occurs in one sector, not in all at the same time. The specific factor model of international trade describes well the effects of an increase in a factor specific to the production of a given product. If two products, food and cloth, are produced and land is assumed to be a factor specific to food production while labor is specific to cloth production, a sudden increase in the arable land would shift out the $P P F$ curve more in the direction of food production (Figure 2(a)). A massive immigration of workers in a country would, respectively, enlarge the economy more in the direction of the labor-intensive industry, i.e., the cloth industry (Figure 2(b)). Biased growth therefore occurs when the $P P F$ curve shifts out more toward one good than toward an-

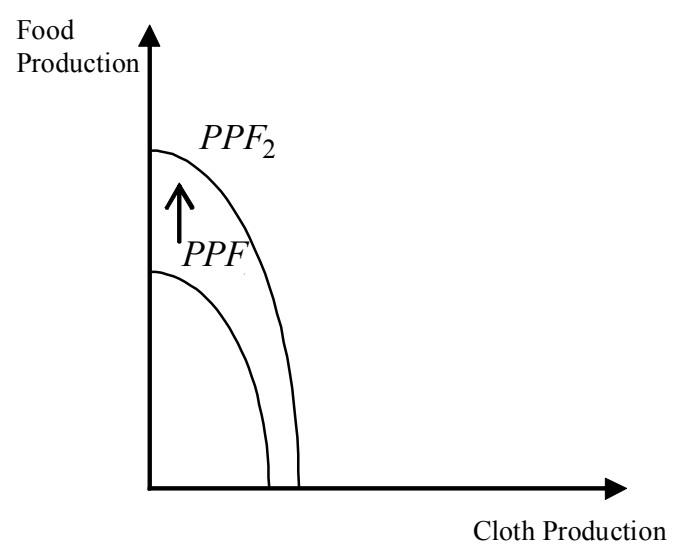

(a) Growth biased toward food other. What is common is that in both cases the $P P F$ is shifted outwards so more of both goods are produced.

The bias is in the direction of the good to which the factor is specific or the production of which is intensive in the factor whose supply has increased. The bias may also result from the uneven distribution of the fruits of technological progress among sectors and the fact that as a result of technological innovation one sector can prosper more than the others.

If the relative price given by the slope of the isovalue line stays the same the result of such a biased growth is increase of one output at the expense of the other. This means that the growth in some sector will be so strong it will absorb resources from the other sector, thus reducing the other sector's net output. The biased effect of growth in one sector due to a resource change was first observed by Rybczynski [16] and is therefore known as the

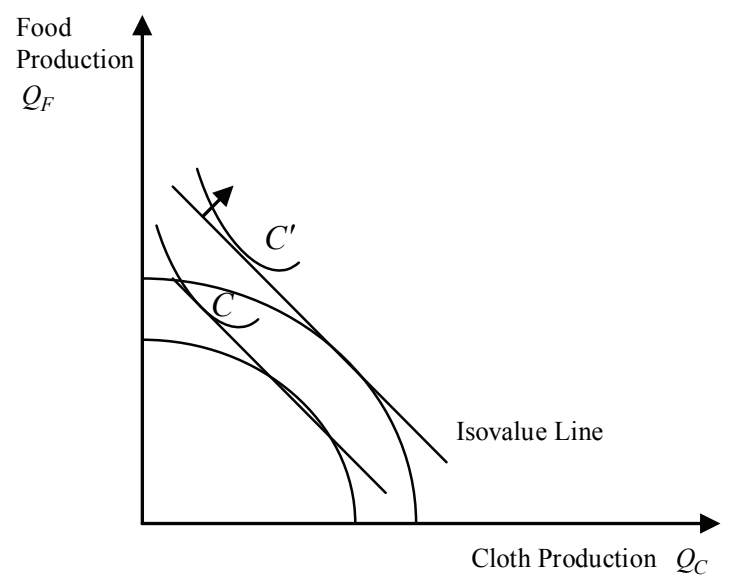

Figure 1. Production and consumption abilities of a country producing two goods before and after growth (constant relative prices).

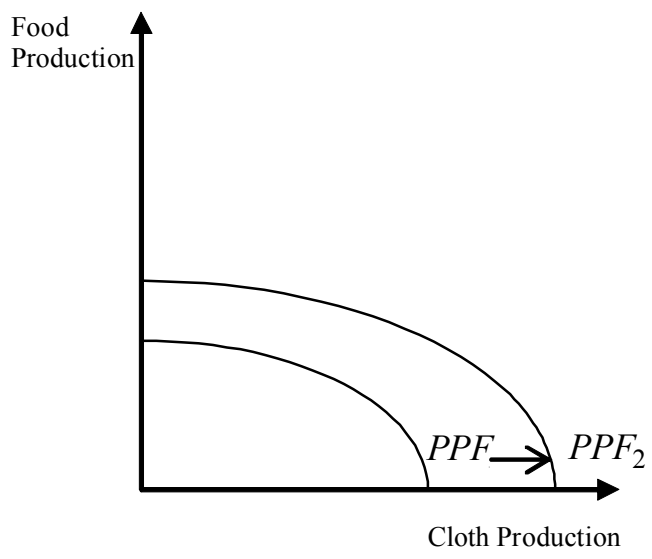

(b) Growth biased toward cloth

Figure 2. Biased growth. 


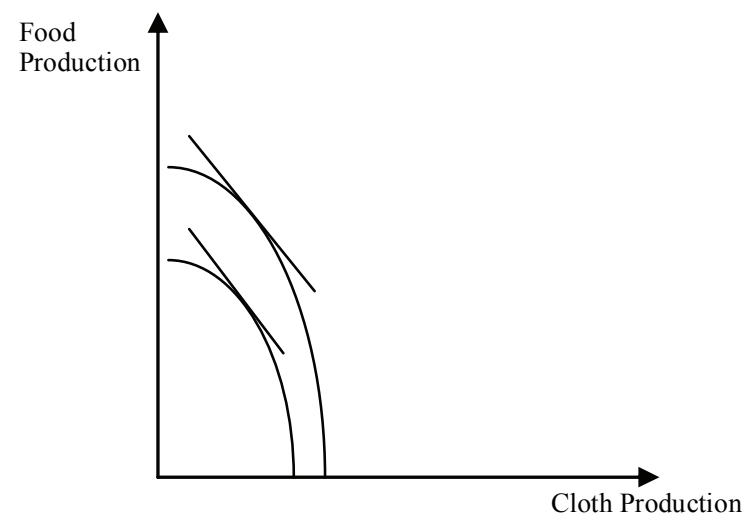

(a) Growth biased toward food

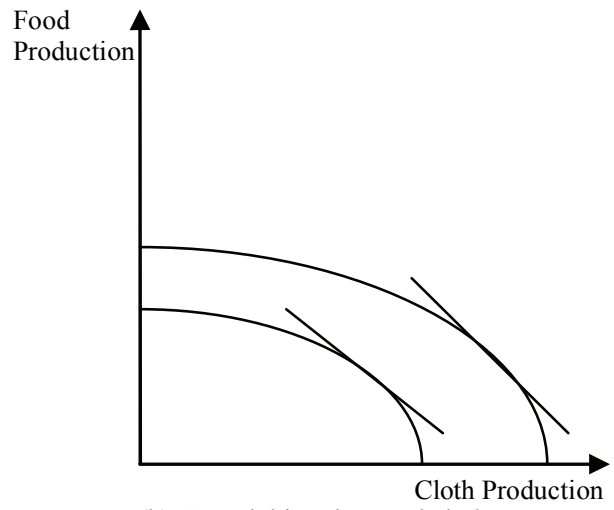

(b) Growth biased toward cloth

Figure 3. Biased growth.

Rybczynski effect. At an unchanged relative price of food in terms of cloth the output of cloth actually falls (Figure 3(a)) and vice versa - when cloth increases food production falls (Figure 3(b)).

Economic growth in a country would affect world relative supply and the terms of trade. The country's economy must be large enough to affect the world production of a given commodity. If the country is strong in cloth production and experiences growth strongly biased toward cloth, while the output of food falls, the effect on world relative supply of cloth in terms of food will be to increase it. The relative supply of cloth in terms of food will, therefore, increase shifting to the right as shown in Figure 4 where $Q_{C}$ and $Q_{F}$ denote the outputs of cloth and food produced by "Home" and $Q_{C}^{*}$ and $Q_{F}^{*}$ those produced by "Foreign" in a two - country world economy. Growth biased toward cloth shifts the $R S$ curve to the right. The opposite movement would occur if growth is biased toward food, that is, if supply of food increases relative to that of cloth. It suffices to discuss one of the cases, cloth - biased growth. Cloth - biased growth increases the relative supply of cloth shifting the $R S$ curve to the right, hence, decreasing the relative price of cloth in terms of food, $P_{F} / P_{C}$. This effect of the falling relative price represents a worsening of the terms of trade for the home, expanding economy and an improvement in the terms of trade for the foreign economy. The world can now obtain the cloth produced in the growing economy more cheaply than before.

This worsening of the terms of trade for the home economy as a result of its growth is the reason why export-biased growth is considered bad for an expanding economy. While export-biased growth is the growth of production of the good the country exports, import-biased growth is that for the commodity, which is imported into the country. It is commonly believed that exportbiased growth worsens a growing country's terms of trade, to the benefit of the rest of the world; while import-biased growth tends to improve a growing country's terms of trade at the expense of the rest of the world. All this occurs through the mechanism of relative prices as the result of the game of relative supply and relative demand. Although such is, indeed, the effect of growth on relative prices, this result does not necessarily imply that growth is bad for an expanding economy. Increased total revenues to domestic producers, who now sell more output, may offset the negative impact of export-biased growth on the terms of trade.

If revenue considerations are ignored, it does not matter which country experiences growth. If foreign countries experience cloth-biased growth, relative prices fall, thus worsening again the terms of trade for the home economy specialized in cloth. Whether the home or the foreign economies increase the supply of cloth the effect on the terms of trade for the home economy would still be negative. Any economy might experience importbiased growth, thus improving the terms of trade for the home economy. If revenues are ignored, the place where growth occurred does not matter. What matters is the

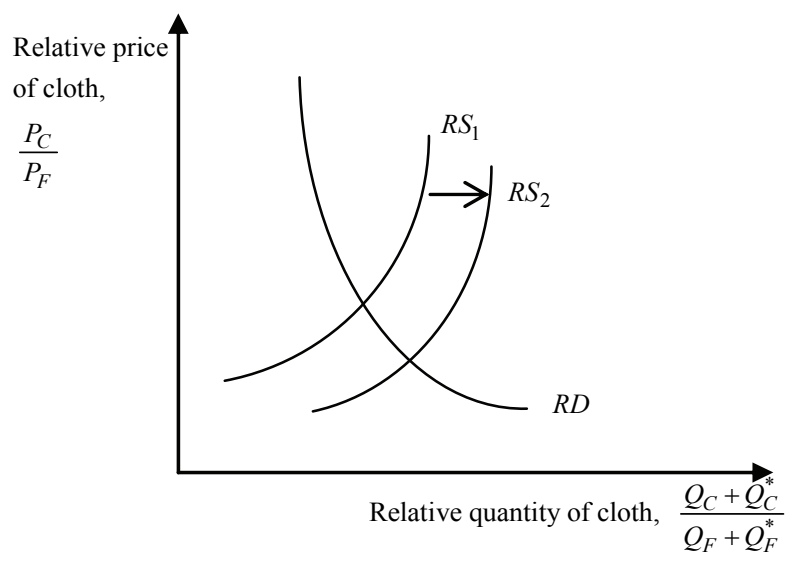

Figure 4. Cloth-biased growth. 
industry or sector, which experienced growth. Growth in export-oriented sectors hurts our economy, while that in import-oriented sectors improves the terms of trade for us, irrespective of where growth occurred - at home or abroad.

However, if one takes revenues into account, it does matter whether growth has occurred domestically and what its bias is. Despite the worsening terms of trade export-biased growth may be good for an expanding economy when it is offset by higher revenues for domestic producers. If export-biased growth has occurred abroad rather than at home, the impact on the home economy would be negative. Worse terms of trade would be combined with stronger competition from the developing foreign countries, competing in our sector where we may be unable to match the lower price of the product. However, if export-biased growth has occurred domestically, so that our economy now exports more of its competitive product, growth would rarely be immiserizing. Krugman and Obstfeld [5] argue that where growth occurs does not matter, but rather the bias of the growth. They conclude:

"During the 1950s, many economists from poorer countries believed that their nations, which primarily exported raw materials, were likely to experience steadily declining terms of trade over time. They believed that growth in the industrial world would be marked by an increasing development of synthetic substitutes for raw materials, while growth in the poorer nations would take the form of a further extension of their capacity to produce what they were already exporting rather than a move toward industrialization. That is, the growth in the industrial world would be import-biased, while that in the less developed world would be export-biased."

Indeed, the trend in the last several decades has been for advanced western nations to find more and more substitutes to the products produced in developing countries. Examples include synthetic rubber, vanilla, and others. Thus, the fear of the developing world of export-biased growth is not ungrounded. At the same time, it seems like developing countries have not quite been able to match the speed with which highly technological, heavy industry sectors have evolved in the developed West. With the exception of the newly industrialized countries most developing nations have lagged behind the industrialized world technologically. Some of those countries such as India have tried to stimulate infant industries such as metallurgy and machine building in their expectations that those would be highly competitive sectors the country has a comparative advantage into. Instead, those sectors have turned out to be not so competitive, while their subsidization has become a burden to the economy. In many countries of the Third World agriculture and light industry have remained the leading exporting sectors. Developing countries have stayed in the lead of the production of apparel, shoes, food and beverages, including coffee, cocoa and tea, etc. Eastern European countries have a comparative advantage in the production of agricultural products and have been major exporters of meat, tomatoes, cucumbers, potatoes, wheat and corn.

Terms of trade worsen as the country, large enough to affect world supply and equilibrium prices, experiences growth. As the world relative supply $R S$ grows, the inevitable result is the fall in the terms of trade (Figure 5). However, not always would worsening terms of trade hurt the expanding economy. The shift in the terms of trade must be sufficiently large in order to offset the positive effects of growth. The fall in the relative price will be insignificant, if $R D$ is elastic, and substantial, if for the same shift in $R S, R D$ is highly inelastic.

On both graphs in Figure 6, as $R S$ shifts to the right as a result of growth in the cloth sector, relative prices fall. However, in the first case (Figure 6(a)) with elastic $R D$ the fall in the relative prices and the worsening of the terms of trade, thereof, are much smaller. In the second case (Figure 6(b)) the fall in the relative prices is substantial which sets the conditions for immiserizing growth. Another important observation is that total revenues increase, as $R S$ shifts right on the first graph, so the effect of the expansion on the economy is actually positive. In the second case there is a fall in $T R$ as the world demand $R D$ is inelastic.

If we assume that the imported commodity includes "all else," the elasticity of demand for which is constant, the elasticity of $R D$ would depend solely on the elasticity of absolute demand for the exported commodity. Let's assume that a country might export one of two commodities. If it exports a good the world demand for which is relatively inelastic, then the elasticity of $R D$ for that good with respect to "all else" would be low.

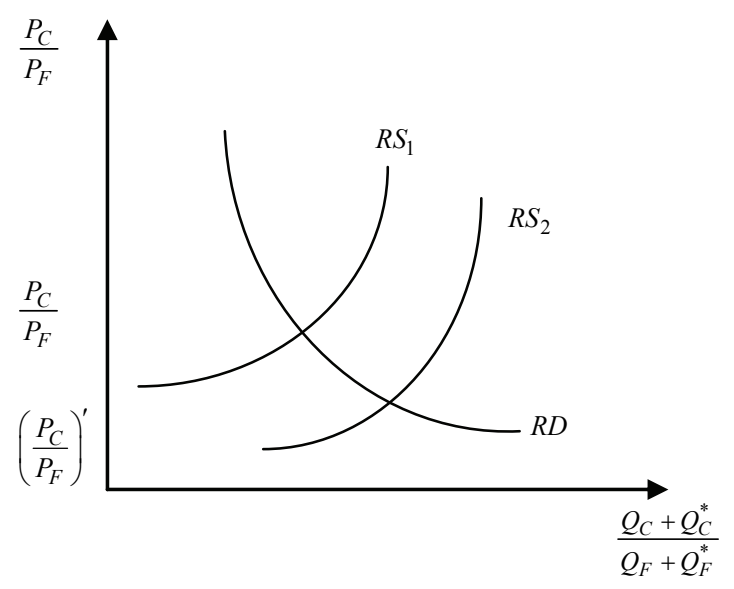

Figure 5. Cloth-biased growth and declining terms of trade. 


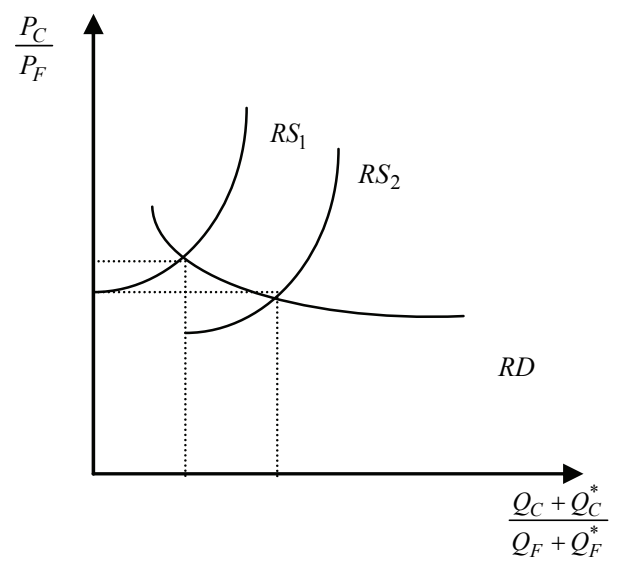

(a) Elastic relative demand

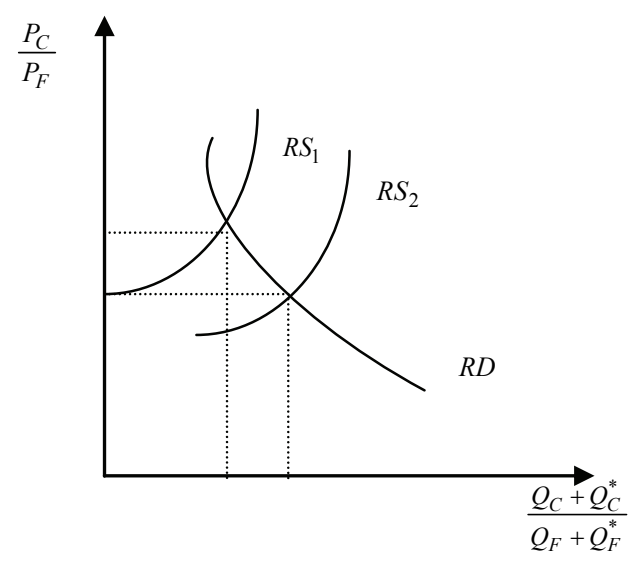

(b) Inelastic relative demand

Figure 6. Terms of trade effects of cloth-biased growth.

Examples of such commodities on the world market may be oil and wheat, which hardly find substitutes in the importing economy. Therefore, oil-exporting countries experiencing growth due to the discovery of new oil deposits would likely face immiserizing growth. This is probably the reason why countries rich in oil have developed collusion practices such as OPEC that do not allow a substantial worsening of the terms of trade. They would be worse off with the extraction of new oil than without it. IMF data show a sharp decline in the terms of trade for oil-exporting countries for the period 1983-1992. The reason for that has been the decline in the price of oil. As world demand for oil is relatively inelastic even minor increases in its supply lead to sharp falls in its price. Table 3 shows the average annual changes in the terms of trade for three groups of countries over two decades. What can be seen is that instead of worsening the terms of trade for the western world for the respective period have actually improved. The reason for that has been the declining price of oil, which at the same time has caused a substantial worsening of the terms of trade for oil exporters.

Similar would be the case on the world wheat market. As the world $R D$ for wheat is relatively inelastic and there are not close substitutes to wheat, a big exporter such as Russia would find itself worse off if new arable land is discovered due to the drying out of marshes, cut-

Table 3. Average annual percent changes in the terms of trade.

\begin{tabular}{ll}
\hline Region & $\mathbf{1 9 8 3 - 1 9 9 2}$ \\
\hline Advanced countries & 1.1 \\
Oil-exporting developing countries & -7.5 \\
Non-oil-exporting developing countries & -0.6 \\
\hline
\end{tabular}

Source: World Economic Outlook, International Monetary Fund, May 2001 ting out of forests or the warming of the climate, all freeing land for agriculture. Smaller producers of wheat such as Hungary and Bulgaria that may not experience the same growth would be affected adversely, as their terms of trade would worsen dramatically.

Akiyama and Larson [12] emphasize that when an adding-up problem exists area expansion will result in welfare losses. They maintain that increasing production through costly expansion of land area should be avoided as that will decrease the producer surplus of existing farmers because of its negative impact on world prices. Furthermore, a devaluation of the country's currency could lead to greater production and exports and thus exacerbate the adding-up problem.

The conclusion is that a country whose exports meet inelastic demand on the world market has no reason to pursue growth and should avoid it in the export-oriented sector. Instead the country would be better off reducing substantially the production of the good, which would inevitably increase its total revenues. Oil exporters' oligopolistic practices have proven that well in time. They have allowed oil-exporting countries to realize substantial gains from trade and experience very favorable terms of trade in the 1970s at the time of the first oil crisis and later during the second one. This has resulted in great trade surplus for them, impressive accumulation of wealth and massive lending of money to non-oil exporting developing countries. Lack of oil and its high prices on the world market rather than greater supply have contributed to the enrichment of oil exporters. As the world price of oil is currently rising and many world conflicts actually take place over oil deposits, one could project improving terms of trade for the countries rich in oil. This would be the trend as the world oil resources get depleted, as the costs of extraction increase and as the pace of discovering new deposits is slowed down. 
At the same time, oil-exporting countries' agreements directed at maintaining high prices of oil are not long lived. This is true for all commodities that have price elasticity of less than one. There have been a number of attempts to establish international agreements to raise commodity prices such as agreements for natural rubber, coffee and cocoa. Such price fixing has proven to be unsuccessful in time and it has turned out to be impossible to support world prices above a market-clearing level for a long time.

Alternatively, countries that export goods the demand for which is elastic should pursue growth strategies. Bhagwati's analysis cannot explain why growth has turned out to be so positive for newly industrialized countries in Southeast Asia and lately for a country like China. These happen to export commodities the demand for which is highly elastic. Examples include clothing, shoes, electrical and home appliances, electronics, etc. Through technological innovation those countries have been able to expand their exports dramatically thus saturating the world market. They have succeeded in replac- ing traditional producers and stealing away a significant market share. Highly innovative products have been the specialty of those countries. Instead of immiserization economic growth has brought to them a competitive edge and a positive trade balance with the rest of the world. An example of that, China's exports to the US continue to exceed the imports from it proving that immiserizing growth, though not impossible, is not a very likely outcome. China's economic success is the result of its economic growth where terms of trade have worsened only slightly but the effects on the national economy have been magnificent. As China has been able to reduce the world relative prices of certain goods substantially, growth has turned out to be by far positive for its development. Anything but immiserizing growth has been observed.

With economic expansion and elastic world relative demand $R D$ the fall of the relative prices is insignificant (Figure 7(a)). At the new relative prices the higher the growth, the greater the gains for the developing economy. Greater growth, rather than smaller, is prefer-
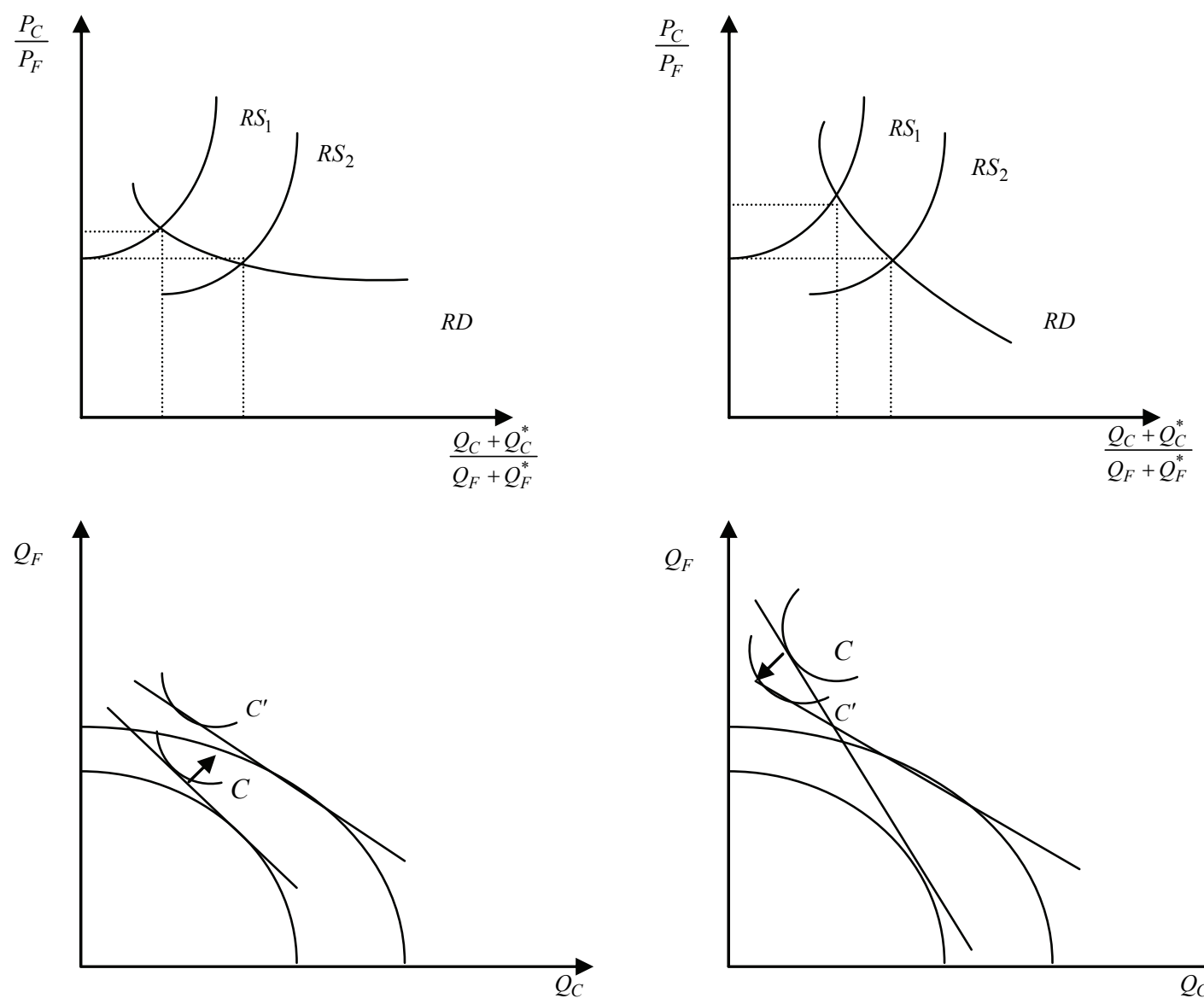

(a) Elastic relative demand

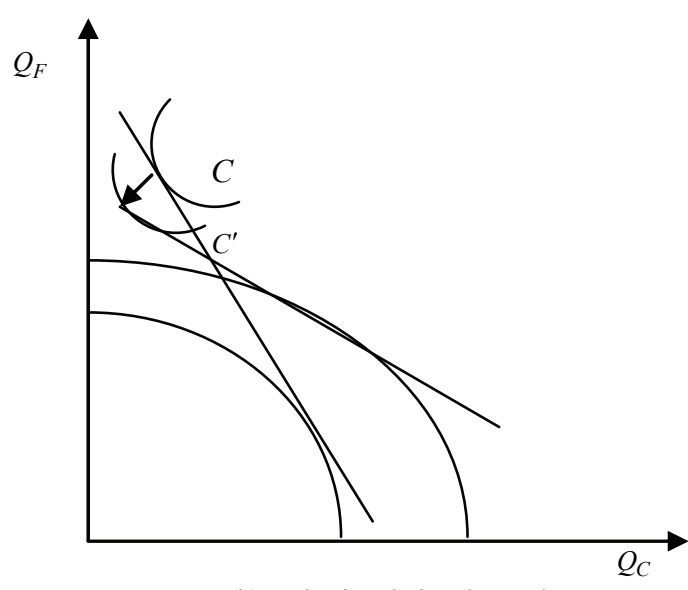

(b) Inelastic relative demand

Figure 7. Economic growth with elastic and inelastic relative demand. 
able for the national economy. As terms of trade worsen only slightly, much greater consumption gains are achieved (shown with a shift to a higher community indifference curve from $C$ to $C^{\prime}$ ). More output is produced and sold bringing in very high revenues for domestic producers from the global market. In the second case of inelastic relative demand the fall in the terms of trade is substantial thus leading the country to a lower consumption point, as depicted by a leftward pivot of the consumption possibilities frontier and consequently a lower community indifference curve (from $C$ to $C^{\prime}$ on Figure 7(b)).

In rare cases it is possible for a country, undergoing economic growth, to face both types of demand. The initial portion of the $R D$ curve might be inelastic and then it might turn highly elastic. What should the consequences of this type of demand be on the home economy?

As the country starts experiencing growth and relative price falls, there may be a substantial worsening of its terms of trade. The nation would have to consume less moving to a lower community indifference curve. At the same time, it might be faced with foreign competition that is able to meet the lower price of the exported commodity. As growth in the domestic economy persists and $R S$ shifts to the elastic part of the $R D$ curve, total revenues begin to grow. At this point, few other countries can mach the low price of the exported commodity, which allows the developing economy to gain a greater market share. Subsequent growth must be large enough to offset the initial loss of wealth, resulting from the shift in the inelastic section.

\section{Data and Evaluation Procedure}

We analyze data on Brazil's exports of green coffee, as

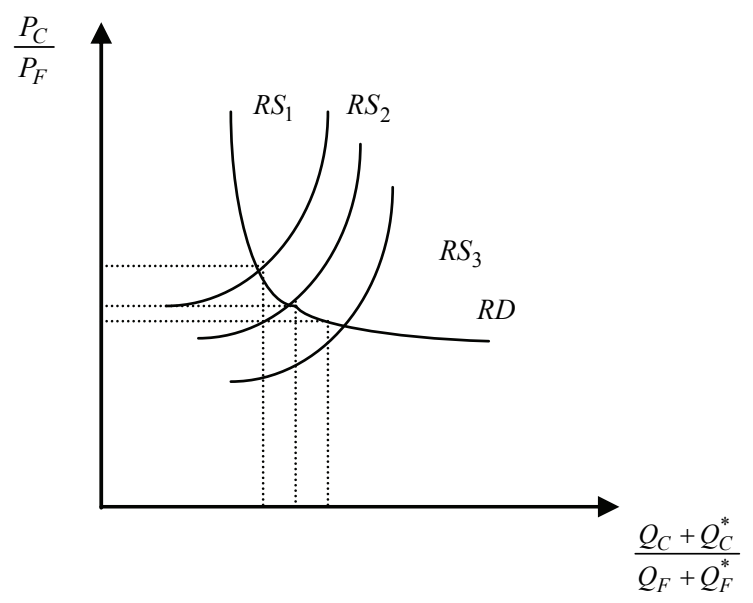

Figure 8. Changes in relative supply in the inelastic and elastic part of the demand curve.
Brazil is its largest exporter with a total quantity exported of 1,410,801 metric tons for 2004 (as shown by Table 4) which is nearly three times more than the exports of the second biggest producer Colombia. Some of the leading exporters of green coffee in the world are Brazil, Colombia, Vietnam, Germany, Indonesia, Guatemala, etc. (see Table 5). The source of the data is the Food and Agricultural Organization and the time-series cover the years 1980 to 2004 [17]. For Brazil green coffee is one of the leading agricultural commodities together with soybeans and sugar (see Table 6). Thus, Brazil is not only able to substantially influence the terms of trade of coffee with respect to a composite good but potential growth in its coffee sector would dramatically affect its terms of trade and welfare. These two factors are the reason why we choose the case of Brazil. The results for Brazil would be valid for any large open economy trading with products the demand for which is relatively inelastic. Similar to Brazil countries like China and Russia represent huge

Table 4. Brazil's total exports of coffee 1980-2004 Source: Food and Agricultural Organization, 2007 Internet available: http://faostat.fao.org.

\begin{tabular}{|c|c|c|c|}
\hline \multicolumn{3}{|c|}{ Brazil's Exports of Coffee } & \multirow[b]{2}{*}{ World GDP } \\
\hline Year & $\begin{array}{l}\text { Quantity } \\
\text { (Mt) }\end{array}$ & $\begin{array}{c}\text { Value } \\
\text { (000 US\$) }\end{array}$ & \\
\hline 1980 & 784465 & 2486055 & $11,741.70$ \\
\hline 1981 & 825443 & 1516646 & $11,941.62$ \\
\hline 1982 & 888023 & 1857539 & $11,779.02$ \\
\hline 1983 & 939671 & 2095749 & $12,083.24$ \\
\hline 1984 & 1031895 & 2564293 & $12,463.33$ \\
\hline 1985 & 1033611 & 2369178 & $12,863.88$ \\
\hline 1986 & 477907 & 2005902 & $15,188.39$ \\
\hline 1987 & 987609 & 1959196 & $17,408.93$ \\
\hline 1988 & 904357 & 2008945 & $19,500.37$ \\
\hline 1989 & 943374 & 1610306 & $20,470.81$ \\
\hline 1990 & 853230 & 1106287 & $22,721.70$ \\
\hline 1991 & 1094694 & 1382331 & $23,913.58$ \\
\hline 1992 & 1017642 & 970442 & $24,100.76$ \\
\hline 1993 & 964153 & 1065184 & $24,656.79$ \\
\hline 1994 & 871018 & 2218688 & $26,488.03$ \\
\hline 1995 & 721305 & 1969869 & $29,390.76$ \\
\hline 1996 & 777909 & 1718593 & $30,079.92$ \\
\hline 1997 & 868439 & 2745289 & $29,927.89$ \\
\hline 1998 & 995212 & 2330874 & $29,682.36$ \\
\hline 1999 & 1271772 & 2230844 & $30,785.54$ \\
\hline 2000 & 967042 & 1559614 & $31,649.87$ \\
\hline 2001 & 1252217 & 1207735 & $31,455.91$ \\
\hline 2002 & 1551410 & 1195531 & $32,714.13$ \\
\hline 2003 & 1369159 & 1302746 & $36,750.97$ \\
\hline 2004 & 1410801 & 1750091 & $41,258.03$ \\
\hline
\end{tabular}


Table 5. Major exporters of green coffee in the world for 2004 Source: Food and Agricultural Organization, 2007. Internet available: http://faostat.fao.org.

\begin{tabular}{|c|c|c|c|c|}
\hline & Country & Quantity (Mt) & $\begin{array}{c}\text { Value } \\
\text { (000 US\$) }\end{array}$ & $\begin{array}{l}\text { Unit value } \\
\text { (US\$) }\end{array}$ \\
\hline 1 & Brazil & 1410801 & 1750091 & 1240 \\
\hline 2 & Colombia & 574935 & 960817 & 1671 \\
\hline 3 & Viet Nam & 974800 & 641022 & 658 \\
\hline 4 & Germany & 221745 & 384743 & 1735 \\
\hline 5 & Guatemala & 208490 & 328006 & 1573 \\
\hline 6 & Peru & 191124 & 289903 & 1517 \\
\hline 7 & Indonesia & 339880 & 283328 & 834 \\
\hline 8 & Honduras & 157729 & 222311 & 1409 \\
\hline 9 & Costa Rica & 108565 & 197640 & 1820 \\
\hline 10 & Mexico & 116626 & 196150 & 1682 \\
\hline 11 & Ethiopia & 134446 & 195026 & 1451 \\
\hline 12 & India & 140613 & 157109 & 1117 \\
\hline 13 & Nicaragua & 79783 & 126773 & 1589 \\
\hline 14 & Uganda & 153275 & 123878 & 808 \\
\hline 15 & El Salvador & 80639 & 123103 & 1527 \\
\hline 16 & $\begin{array}{l}\text { United States } \\
\text { of America }\end{array}$ & 73331 & 118346 & 1614 \\
\hline 17 & Côte d'Ivoire & 142082 & 105504 & 743 \\
\hline 18 & Belgium & 66606 & 103283 & 1551 \\
\hline 19 & $\begin{array}{l}\text { Papua New } \\
\text { Guinea }\end{array}$ & 63000 & 88089 & 1398 \\
\hline 20 & Kenya & 48643 & 87771 & 1804 \\
\hline
\end{tabular}

exporters that influence the terms of trade in various sectors. However, unlike Brazil those two large economies export diverse commodities, not few, and many of their exported goods face elastic demand on the world market. In other words, in the case of these two countries we speak of diversified economy rather than one-sector, one-product oriented foreign trade.

If the world demand for green coffee is price inelastic and Brazil as a huge exporter of coffee decides to increase its exports, it will have a profound effect on smaller exporters for which the share of coffee in total exports is substantial. Such is the case with Burundi whose world share is small $(0.7 \%)^{2}$. Even large changes in Burundi's exports of green coffee could not influence world prices. At the same time, Burundi has $85 \%$ of its total exports coming from coffee.

In the past coffee exports had for a long time been subject to control under the International Coffee Agreement where each exporting member country had been allocated part of a global export quota. The expressed purpose of the Agreement had been to stabilize prices but ultimately the export control was used to attempt to raise average coffee prices. The export quota system of the

${ }^{2}$ According to Imran and Duncan [14].
Table 6. Major agricultural goods exported by Brazil in 2004 Source: Food and Agricultural Organization, 2007 Internet available: http://faostat.fao.org.

\begin{tabular}{|c|c|c|c|c|}
\hline & Commodity & $\begin{array}{l}\text { Quantity } \\
\text { (Mt) }\end{array}$ & $\begin{array}{c}\text { Value } \\
\text { (000 US\$) }\end{array}$ & $\begin{array}{l}\text { Unit value } \\
\text { (US\$) }\end{array}$ \\
\hline 1 & Soybeans & 19247690 & 5394907 & 280 \\
\hline 2 & $\begin{array}{l}\text { Cake of Soya } \\
\text { Beans }\end{array}$ & 14485622 & 3270889 & 226 \\
\hline 3 & Chicken Meat & 2424520 & 2493930 & 1029 \\
\hline 4 & $\begin{array}{l}\text { Beef and Veal, } \\
\text { Boneless }\end{array}$ & 923659 & 1961465 & 2124 \\
\hline 5 & Coffee, Green & 1410801 & 1750091 & 1240 \\
\hline 6 & $\begin{array}{l}\text { Sugar (Centrifu- } \\
\text { gal, Raw) }\end{array}$ & 9565749 & 1510983 & 158 \\
\hline 7 & Oil of Soya Beans & 2517244 & 1382095 & 549 \\
\hline 8 & Tobacco Leaves & 579365 & 1380461 & 2383 \\
\hline 9 & Sugar Refined & 6198182 & 1129247 & 182 \\
\hline 10 & $\begin{array}{l}\text { Oranjuice Con- } \\
\text { centrated }\end{array}$ & 1010258 & 789683 & 782 \\
\hline 11 & Maize & 5030999 & 597336 & 119 \\
\hline 12 & Pork & 335684 & 566400 & 1687 \\
\hline 13 & $\begin{array}{l}\text { Alcohol Non Food } \\
\text { Purpose }\end{array}$ & 1926759 & 497814 & 258 \\
\hline 14 & Beef Preparations & 171176 & 446979 & 2611 \\
\hline 15 & Cotton Lint & 331044 & 406070 & 1227 \\
\hline 16 & Coffee Extracts & 80350 & 299333 & 3725 \\
\hline 17 & $\begin{array}{l}\text { Oranjuice Single- } \\
\text { Strengt }\end{array}$ & 573799 & 268408 & 468 \\
\hline 18 & Turkey Meat & 134339 & 212432 & 1581 \\
\hline 19 & Wheat & 1323433 & 207801 & 157 \\
\hline 20 & Food Prepared nes & 103044 & 200434 & 1945 \\
\hline
\end{tabular}

International Coffee Agreement stopped working in 1989 when the members had a disagreement on the rules of operation of the quota system. The United States has acceded to the 2001 International Coffee Agreement, and has become a member of the International Coffee Organization in 2005. The International Coffee Organization facilitates world coffee trade and helps coffee farmers improve quality and access global markets.

We use exports data, in particular, the total quantity exported of green coffee in metric tons and the unit value of a ton of exports in USD. Figure 9 depicts this relationship. We use the unit value as a measure of the unit export price of the commodity. It is obtained as the ratio of the total value of exports of green coffee in thousands of USD and the total quantity exported. Furthermore, we follow the methodology of Hallam et al. who use real Gross Domestic Product as a proxy for income in the estimation of the demand function where it is believed that income is highly correlated with GDP. We use world GDP at current prices in USD as given by the World Economic Outlook Database, September 2006 [18]. We tried several specifications in view of the simultaneity bias 


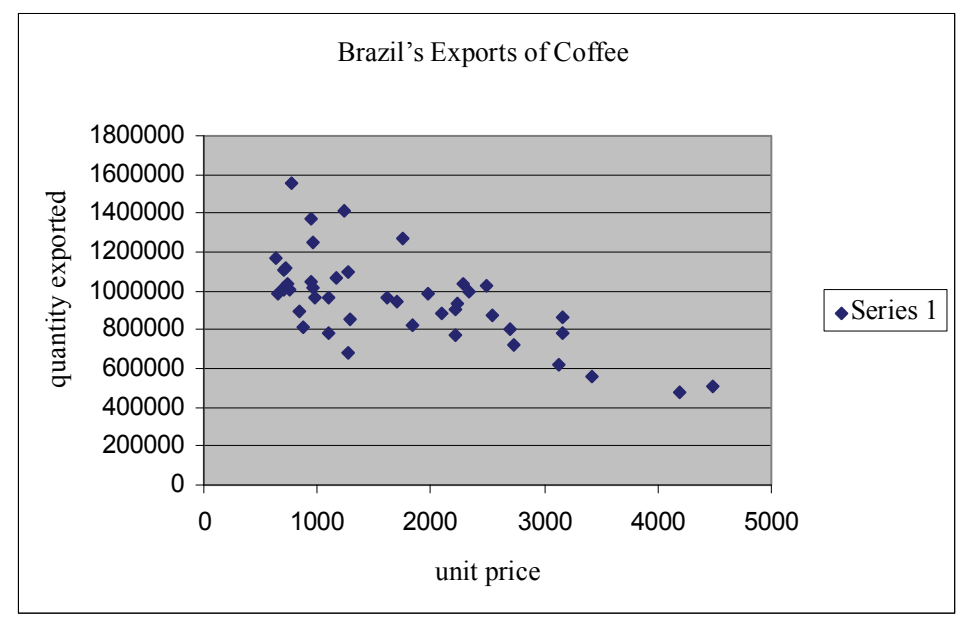

Figure 9. Brazil's exports of coffee.

which results from the fact that quantity produced by Brazil and demanded by the world and the export price of coffee are endogenous variables. All demand functions were estimated using OLS. Initially, we estimated the direct demand function using a linear demand-function equation

$$
Q_{t}=\beta_{o}+\beta_{1} P_{t}+\beta_{2} G D P+\varepsilon
$$

and a log-linear demand function equation

$\ln Q_{t}=\beta_{o}+\beta_{1} \ln P_{t}+\beta_{2} \ln G D P+\varepsilon$

Then, as the specification implies that quantity produced is pre-determined, we estimated an inverse-demand function where we took export price to be dependent on quantity exported and the GDP thus taking into account the endogeneity of the export price of Brazilian coffee. This gives rise to the following two equations

$$
P_{t}=\alpha_{o}+\alpha_{1} Q_{t}+\alpha_{2} G D P+\varepsilon
$$

and

$$
\ln P_{t}=\alpha_{o}+\alpha_{1} \ln Q_{t}+\alpha_{2} \ln G D P+\varepsilon
$$

The results for the first estimation equation are

$$
Q_{t}=1,163,944-177.23 P_{t}+7.46 G D P
$$

$$
\begin{array}{ll}
(41.38) & (3.9) \\
t=-4.28 & 1.9 \\
n=25 & \bar{R}^{2}=0.59
\end{array}
$$

where price is statistically very significant at the $0.03 \%$ level of significance. Income level does not seem to be statistically significant at the 5\% level. The estimated demand equation explains $59 \%$ of the total variation in export volumes. The $F$-statistic shows very good overall fit of the equation. The second estimation equation is

$$
\begin{array}{rl}
\ln Q_{t}=15.98- & 0.39 \ln P_{t}+0.072 \ln G D P \\
(0.087) & (0.093) \\
t=-4.48 & 0.768 \\
n=25 & \bar{R}^{2}=0.55
\end{array}
$$

where world GDP seems to have a very low coefficient and is not statistically significant. A slightly lower ad- justed $R$-square shows a worse goodness of fit but still $55 \%$ of the variation in quantity demanded is explained by the estimated equation. At the same time, price is statistically significant at $0.01 \%$ and its $\beta=-0.39$ gives the own-price elasticity of demand for Brazilian coffee. We obtain an elasticity of less than unity which implies that a large exporter of green coffee like Brazil may be faced with immiserizing growth and an adding-up problem if it expands its land area substantially (for example, by clearing rainforests) and increases its overall production of coffee substantially. In such a case smaller producers and exporters of coffee would be affected negatively as well. Our estimate of the price elasticity of demand for Brazil's coffee is higher than the one found by Imran and Duncan [14] for the world import demand for coffee. From Table 1 this long-run import demand elasticity is -0.23 which is less than the estimated -0.39 for Brazil. At the same time, the two authors estimate shortrun import demand elasticity for Brazil to be -1.2 , while the long-run one is -4.9 (see Table 7). Based on their estimates Imran and Duncan [14] conclude that Brazil and Colombia are justified in increasing their export taxes considerably. Our computed elasticity for Brazil's green coffee is close to the higher-end value found with the help of the World Coffee Model of FAO which lies between -0.1 and -0.37 .

From the third estimation equation we obtain a linear inverse-demand function

$$
\begin{array}{cc}
P_{t}=4609.47-0.0025 Q_{t}-0.0042 G D P \\
(0.00056) & (0.016) \\
t=-4.28 & -0.26 \\
n=25 & \bar{R}^{2}=0.52
\end{array}
$$

where both the coefficients of quantity and GDP as the independent variables tend to zero and the one of GDP seems not to be statistically significant. That of price is 
Table 7. Import demand elasticity facing major suppliers of coffee as estimated by Imran and Duncan [14].

\begin{tabular}{lcc}
\hline & $\begin{array}{c}\text { Short-run Import } \\
\text { Demand Elasticity }\end{array}$ & $\begin{array}{c}\text { Long-run Import } \\
\text { Demand Elasticity }\end{array}$ \\
\hline Brazil & -1.2 & -4.9 \\
Colombia & -2.4 & -10.5 \\
Cote D'Ivoire & -5 & -25.5 \\
Kenya & -14.8 & -73.7 \\
World & -0.17 & -0.23 \\
\hline
\end{tabular}

significant at the $0.03 \%$. Finally, we run a regression for a log-linear inverse-demand function

$$
\begin{aligned}
\ln P_{t}=26.29-1.22 \ln Q_{t} & -0.187 \ln G D P \\
(0.27) & (0.163) \\
t=-4.48 & -1.14 \\
n=25 & \bar{R}^{2}=0.56
\end{aligned}
$$

which shows a better adjusted $R$-square than the linear inverse-demand function equation. In this last case quantity turns out to have a higher coefficient than in the linear inverse-demand equation and is statistically significant at the $0.01 \%$ level of significance.

We use the example of coffee to illustrate the possible cases of immiserizing growth. Those are likely to occur for commodities the demand for which is highly inelastic. We have identified coffee to be one such commodity where we found the price elasticity of demand for Brazil's coffee to be low, -0.39 . Coffee represents a primary commodity and a homogeneous good the price of which is known and easy to establish. It would be interesting to try to apply the same framework and analysis for manufactured, heterogeneous goods for which it could be expected that world demand would be elastic. Our empirical data prove the theoretical model in the part on inelastic demand. Since Brazil exports coffee the demand for which is inelastic we establish that the country is likely to face immiserizing growth. For other countries exporting commodities facing high world demand elasticity however it is unlikely that they will be faced with immiserizing growth and an adding up problem.

\section{Conclusions}

Theoretically, it is possible for a growing economy to experience the adverse effects of growth. This would be the case when, as a result of expanding its productive capacity, the terms of trade of a country deteriorate so much it becomes worse off than before growth. In such a situation all the positive effects of economic growth would be offset by the declining buying power of the nation. However, we have tried to illustrate when growth is likely to be positive and negative on the expanding economy. We have shown that immiserizing growth is less likely to occur than is generally predicted. It will occur only when for a given increase in world relative supply of a given commodity relative demand for it is inelastic. This would likely be the case when there are no close substitutes for the commodity in the importing countries or globally. However, world trade gives ample examples of situations when world demand for particular goods is elastic. As a result of that their exporters have become relatively wealthier, not poorer. Therefore, immiserizing growth seems to be a rather hypothetical situation with few practical implications. Economic reality shows that many developing countries are better off with growth rather than without it.

\section{REFERENCES}

[1] J. Bhagwati, "Immiserizing Growth: A Geometrical Note," The Review of Economic Studies, Vol. 25, No. 3, June 1958, pp. 201-205.

[2] J. Bhagwati, A. Panagariya and T. N. Srinivasan, "Lectures on International Trade," 2nd Edition, MIT Press, Massachusetts, 1998.

[3] H. G. Johnson, "Economic Expansion and International Trade," The Manchester School, Vol. 23, No. 2, May 1955, pp. 95-112.

[4] E. Dinopoulos, "Immiserizing Growth in Expanding Economies," Note Prepared for the Conference in Honor of Jagdish Bhagwati's 70th Birthday at Columbia University, 5-6 August 2005.

[5] P. Krugman and M. Obstfeld, "International Economics: Theory and Policy," 6th International Edition, Addison Wesley, Massachusetts, 2003.

[6] H. G. Johnson, “The Possibility of Income Losses from Increased Efficiency or Factor Accumulation in the Presence of Tariffs," The Economic Journal, Vol. 77, No. 305, March 1967, pp. 151-154.

[7] H. Uzawa, "Liberalization of Foreign Investments and the National Economy," Economisuto (in Japanese), Vol. 23, No. 1, December 1969, pp. 105-122.

[8] K. Hamada, "An Economic Analysis of the Duty-Free Zone," Journal of International Economics, Vol. 4, No. 3, August 1974, pp. 225-241.

[9] R. A. Brecher and C. F. Diaz-Alejandro, "Tariffs, Foreign Capital and Immiserizing Growth," Journal of International Economics, Vol. 7, No. 4, November 1977, pp. 317-322.

[10] K. Hamada and K. Iwata, "National Income, Terms of Trade and Economic Welfare," The Economic Journal, Vol. 94, No. 376, December 1984, pp. 752-771.

[11] Y. Sawada, "Immiserizing Growth: An Empirical Evaluation," CIRJE Discussion Papers F-Series, CIRJE-F-235, CIRJE, Faculty of Economics, University of Tokyo, Tokyo, 2003.

[12] T. Akiyama and D. F. Larson, "The Adding-up Problem: Strategies for Primary Commodity Exports in Sub-Saha- 
ran Africa," Policy Research Working Paper 1245, World Bank, International Economic Department, Washington DC, 1994.

[13] H. G. Johnson, "Equilibrium Growth in an International Economy," The Canadian Journal of Economics and Political Science, Vol. 19, No. 4, November 1953, pp. 478500.

[14] M. Imran and R. Duncan, "Optimal Export Taxes for Exporters of Perennial Crops," Policy, Planning and Research Working Papers, WPS10, World Bank, International Economic Department, Washington DC, 1988.

[15] D. Hallam, P. Liu, G. Lavers, P. Pilkauskas, G. Rapsomanikis and J. Claro, "The Market for Non-Traditional
Agricultural Exports," FAO Commodities and Trade Technical Paper 3, Raw Materials, Tropical and Horticultural Product Service Commodities and Trade Division, Food and Agriculture Organization of the United Nations, 2004.

[16] T. M. Rybczynski, "Factor Endowment and Relative Commodity Prices," Economica, New Series, Vol. 22, No. 88 , November 1955 , pp. 336-341.

[17] Food and Agricultural Organization, 2007. http://faostat. fao.org

[18] World Economic Outlook, International Monetary Fund, May 2001, 2006. 